\title{
The Tholiban Brigade Political Da'wah Movement in Tasikmalaya
}

\author{
Dadang Kuswana
}

UIN Sunan Gunung Djati Bandung, Indonesia

*email.dadang.kuswana@uinsgd.ac.id

\begin{abstract}
This study aims to analyze the existence of the Tholiban Brigade movement in Tasikmalaya as a socioreligious movement. The research aims to answer the existence, motives, and transformation of the Tholiban Brigade da'wah movement in the political field. The research was conducted through a qualitative approach through descriptive methods. Data collection was carried out through observation, interviews, and literature study. The results showed that the legalization of Islamic law in the state's formal law was carried out by the Tholiban Brigade to actualize Islamic da'wah towards Islamic daulah. The legalization of Islamic law is carried out in aspirations, participation, coalitions, and regional political bargaining. The motive of the Tholiban Brigade political da'wah movement is the spirit of amar maruf nabi munkar both in individual and social spheres. This is an effort to change the social order towards Islamic life as a whole (kaffah). The transformation of the da'wah movement towards the Brigade Tholiban political movement is based on religious teachings that view Islam as a religion and state. The implication of this research is expected to map the existence of the Tholiban Brigade political da'wab movement in the national political constellation.
\end{abstract}

Keywords: da'wah movement; political movement; Brigade Tholiban; syariat Islam.

\begin{abstract}
ABSTRAK
Penelitian ini bertujuan untuk menganalisis eksistensi gerakan Brigade Tholiban di Tasikmalaya sebagai sebuah gerakan sosial keagamaan. Penelitian diarahkan pada upaya menjawab eksistensi, motif dan transformasi gerakan dakwah Brigade Tholiban dalam bidang politik. Penelitian dilakukan melalui pendekatan kualitatif melalui metode deskriptif. Pengumpulan data dilakukan melalui observasi, wawancara dan studi pustaka. Hasil penelitian menunjukkan bahwa legalisasi syariat Islam dalam hukum formal negara dilakukan oleh Brigade Tholiban sebagai upaya aktualisasi dakwah Islam menuju daulah Islamiyyah. Legalisasi syariat Islam dilakukan dalam bentuk aspirasi, partisipasi, koalisi dan bargaining politik daerah. Motif gerakan dakwah politik Brigade Tholiban adalah spirit amar maruf nahi munkar baik pada lingkup individual maupun sosial. Transformasi gerakan dakwah menuju gerakan politik Brigadi Tholiban didasarkan pada doktrin ajaran agama yang memandang Islam sebagai agama dan negara. Implikasi penelitian ini diharapkan mampu memetakan eksistensi gerakan dakwah politik Brigade Tholiban dalam konstalasi politik nasional.
\end{abstract}

Kata Kunci: gerakan dakwah; gerakan politik; Brigade Tholiban; syariat Islam. 


\section{INTRODUCTION}

After the fall of the New Order regime, religious movements' symptoms have returned to strength, both in the form of religious-based ideology, political movements, and acts of separatism. Reformasi was used as an expression of the pressure from the New Order regime for years. Reform is a pandora valve in expressing specific ideological ideas and movements. Phenomenon and symptoms of the strengthening of religious ideology occur not only in cities but also in regions, among the ideological groups in Islam that have returned to work in several areas in West Java, such as Hizbut Tahrir Indonesia (HTI), the Islamic Defenders Front (FPI), the Mujahidin Council (MM) and the Tholiban Brigade (BT).

The Islamic ideological movement developed with various motivations, both with economic, political, and Islamic preaching motives. The Islamic ideological movement group is used as a political patron for regional leaders such as regents and mayors. There is a commitment between them to cultivate a symbiotic relationship with mutualism, as was done by the Tholiban (BT) Brigade in Tasikmalaya. As a religion-based ideological group, BT carries the jargon amar ma'ruf nahi munkar or da'wah. However, their da'wah methods and approaches tend to lead to extremism, which triggers pro and contra attitudes in society. It mainly refers to members of society who have a more gentle and moderate understanding and Islam approach.

Reformation-era provided room for freedom of expression, freedom of the press, and freedom of association, which had long been suppressed by the New Order government. This situation continues to affect both urban and rural communities. The BT movement tends to be accepted by the Tasikmalaya people to develop and get reinforcement from various parties, especially the santri group. The BT movement was declared in 2006 as a community organization in Tasikmalaya, which is officially named the Tholiban Brigade.

The Tholiban Brigades have an essential role in playing local, regional politics. BT has succeeded in marketing their romantic ideas to be accommodated in the realm of positive law, such as the targets of Islamic ideas manifested in the form of Regional Regulations or Perda. The actualization of the BT group's Islamic ideals to become large, broadcast, and legal is carried out with various approaches, such as local politics, history, and religious sentiments. 
The influence of the International Islamic movement and domestic politics is also thought to have contributed to the growth and development of religious, ideological groups in the regions. It is seen as a result of the development of infiltrated information technology in most Indonesians' lives, both in urban and rural areas. This influence can be seen from the domestic political constellation, which shows a tendency for BT movements and strategies to be more political in the general elections for legislative members, both at the central and regional levels. In the 2009 Election, the Tasikmalaya Tholiban Brigade was recorded as having succeeded in the success of 1 representative in the Indonesian Parliament (DPR RI), one person in the Provincial (DPRD), and 21 people in the Tasikmalaya City (DPRD) (Hasani \& Naipospos, 2010: 184). This political movement and strategy were carried out to achieve the target of the Tholiban Brigade Islamic ideas and ideals into a legal and readily accepted policy by the public.

The democratization that was played 16 years ago provides more flexibility for groups like BT to collaborate and coalitions with regional leaders and support regional leadership candidates to get policy support that supports their movements. However, BT's ideas and movements have been shown to have provoked reactions from other groups and adherents of Islamic ideology that is more established and "non-political," such as the pesantren in Tasikmalaya. The reaction of this pesantren group is not limited to differences in approaches and methods of da'wah. There are also differences in understanding of ethical concepts that originate in the Koran and the struggle for influence in society (Aripudin, 2013).

The BT movement has several times carried out acts of mass mobilization and acts of violence against people who have violated religious ethics. For example, the Sweeping Action was carried out against nightclubs, liquor places, the arrest of community members who committed immoral acts, to political pressure on the local government to allow mining development and exploration which he considered tarnished the justice of the local community, as happened in the Central Panca district. These actions and actions were carried out as a concrete form of commitment by BT members that must be fought for Islamic values.

The actions and actions of the BT group as above, are not the only goals of the BT movement, other agendas that cannot be separated from this group such as the issue of understanding Islamic philanthropy, both related to ways of consuming and distributing it, views on jihad and ways 
of doing it, as well as an understanding of leadership concepts that must be actualized and applied in the lives of Muslims (Chandrasekaran, 2002).

Besides, BT's view of an "Islamic state" seems to be one of the central ideas. It is related to how to maintain Islam and Muslims. In his view, to achieve the ideals of daulah Islamiyah, all Muslim community components must carry out the stages as done by Rasulullah in Mecca. One of them is related to applying and actualizing the concept of "hijrah," which is seen as the starting point in achieving an "Islamic state." BT also does not feel awkward about doing "political training" with the authorities or political figures to get "financial assistance." The strong ties of mass militancy serve as the reason that they have a large and influential mass. A small portion of their financial gain was distributed to BT members, while their leaders used the rest to build mosques, madrasahs, or majlis taklim (Interview with AS, April 2013).

An important question related to B's's'T's role and existence in Tasikmalaya is about how the process of actualizing the BT group's ideals to get broad support from the people of Tasikmalaya. The essential concepts he developed then gave birth to a communication network that regulates the relationship between them and outside their group to become a social movement with religious nuances. The re-strengthening of the "local religious" us" movement as"happened in Tasikmalaya is interesting to reveal because it has become a movement highlighted regarding its actions that have generated pros and cons.

In this regard, the strengthening of social and political-religious movements after the 1998 New Order can be seen from several previous studies. Several studies have examined the relationship between dakwah and politics, for example, Rosa's (2014) research on the politics of da'wah and political da'wah in the reform era. This study analyzes the Dzikr Council, which is positioned as a da'wah entity by President SBY. The results showed that the Dzikr Nurussalam Council's existence as part of a socio-religious movement could not be separated from the political interests of Susilo Bambang Yudhoyono's interest group. Another research was conducted by Ja'far (2015), who analyzed the socio-religious movement of the Naqshabandiyyah Syekh Hasan Maksum Tarekat in North Sumatra. The study results concluded that the religious social movement of the tarekat has a significant influence on society. This influence is felt not only in the religious and social aspects, including in the political aspect. Nirwana's research (2016) analyzes the relationship 
between politics and da'wah in Indonesia. The results show that power or politics is seen as having a significant role and being used as a medium in achieving Islamic preaching goals.

Meanwhile, several studies that take the object of study of religious community organizations include Dodi (2017). The research took the object of the Indonesian Islamic Da'wah Institute (LDII). It is concluded that the LDII organization has experienced a metamorphosis of a movement that is perceived as a heretical organization, becoming a socioreligious movement with a new paradigm in the context of social, economic, cultural, and bureaucratic relations. Nugraha's research (2018) analyzes socio-religious movements based on economics. The research was conducted on BMT in Bandung Regency. The results showed that Muslim identity politics influenced the growing religious, economic movement in rural areas. This transformation occurs in strategic spaces such as economic and political interests. This conclusion is confirmed by Gunawan's research (2018), which states that society's social transformation is carried out to achieve the vision and mission of the movement, including related to religious, social movements.

Muslim research (2019) analyzes the emergence of the Islamic Defenders Front (FPI). Since its emergence, FPI has often been considered controversial and radical in taking specific actions and actions. FPI's political relations have been considered intense since its involvement in the 212 Action to Defend Islam (ABI) related to religious blasphemy. In its development, the FPI movement cannot be separated from radicalism and extremist movements' perceptions. Setiadi's research (2019) explores the phenomena of radical ideology, global jihad, and religious terrorism sprouted in Indonesia, even though socio-religious movements. This phenomenon is alleged to be the global implication of Muslim identity politics and infiltrate Islamic community organizations in Indonesia. It is concluded that acts of radicalism, global jihad, and terrorism directly impact religions and their adherents. These actions cannot be separated from the existence of specific political interests and powers. Kuswana's research (2020) analyzes the Brigade Tholiban group's ideological transformation in playing a role in power/politics. It was concluded that the Tholiban Brigade saw the importance of power to strengthen its Islamic ideas and ideals.

The fundamental issues seem to still revolve around economic issues and da'wah. This potential got its momentum in the era of democracy and political freedom in post-reform Indonesia. The pre-existing socio-political 
potential is also a potent trigger for the community. Community support, especially productive youth, is increasingly becoming a signal to young people's problems in life's increasingly complex and challenging. So significant is the re-emergence of religious movements in the regions that requires seriousness in overcoming it. The problem's breadth and complexity require more specific research and go to the heart of the problem.

This study seeks to analyze social movements and political da'wah from the Tholiban Brigade group in Tasikmalaya. Research is based on the assumption that local religious movements have a decisive socio-political role and influence the surrounding communities. This local religious movement has strengthened since the reformation and after the fall of the New Order regime. This research object is all things related to social movements and the political da'wah of the Tholiban Brigade group in Tasikmalaya. It includes the objectives, driving factors, and transformation of the social movement into the Tholiban Brigade political movement. Meanwhile, this study's subjects were groups or community organizations of the Tholiban Tasikmalaya Brigade. This research uses a qualitative approach with descriptive study methods. These approaches and methods were chosen to explore, analyze, map, and describe the social movements and political da'wah of the Tholiban Brigade organization.

\section{RESULT AND DISCUSSION}

\section{The Existence of Political Da'wah Movement of Brigade Tholiban}

One of the most prominent and radical mass organizations in Tasikmalaya is the Tholiban Brigade. It can be seen from his actions in suppressing immoral behavior. The Tholiban Brigade is one of the organizations that carry out prevention and anti-immoral actions. The Tholiban Brigade was led by Ajengan Zenzen (late) from the Sulalatul Huda Tasikmalaya Islamic Boarding School. Ajengan Zenzen is known to have expertise in politics. As what happened on May 3, 2010, in the South Tasikmalaya region.

After participating in the grand tabligh event at the Nurul Jaza Hegarmanah Islamic boarding school, Bantarkalong District, the Tholiban Brigade period carried out a sweeping liquor action Bantarkalong and Karangnunggal areas, South Tasikmalaya. They confiscated liquor bottles and lottery gambling sold installs (Aripudin, 2013). The Tholiban Brigade was born out of concern about the rampant immoral actions in Tasikmalaya after the 1998 reformation. Various obscenities were shown even near 
places of worship. For example, the Great Tasikamalaya mosque area is often used as a place for prostitution and a place for drunkenness. They were responding to this situation Ajengan Zenzen together with KH. Asep Mousul Affandi gathered ajengan and ulama from various Islamic organizations to respond to this situation.

They then agreed to form the Tasikmalaya Islamic Community Gathering Forum. This forum inspired and encouraged the birth of the Tholiban Brigade in 1999. After being founded, Tholiban established itself as an anti-immoral Islamic organization in Tasikmalaya. They are diligent in confronting various immoralities, such as gambling, prostitution, and liquor circulation. Tholiban is not just an anti-immoral Islamic organization. However, also struggling to uphold Islamic law. When this mass organization was established, the political situation in Tasikmalaya benefited them, significantly to push the agenda for motivating Islamic law into various regional regulations.

In a political context, the Tholiban Brigade can build communication and coalitions with candidates for regents or mayors. It is a manifestation of Islamic politics (siyasah) to the success of regional sharia regulations. For example, in the 2007 elections for the city of Tasikmalaya, the Tholiban Brigade supported Syarif Hidayat as mayor. The mayor paid this support by issuing Perda no. 12/2009 concerning the Development of Social Values based on the Teachings of the Islamic Religion and the Social Norms of the City of Tasikmalaya People.

In other cases, for example, in the 1999 elections, Islamic parties won significant votes. At that time, PKB won five seats, PAN four seats, PBB two seats, and PPP won 11 seats and won the election in Tasikmalaya. The Tholiban Brigade used this Islamic party's victory to push for regional regulations with Islamic law's nuances. Moreover, the Tholiban Brigade figures and other mass organization figures such as FPI have a particular affinity with Islamic parties.

Efforts to enforce Islamic law are increasingly wide open after Tatang Farhanul Hakim, Chairperson of PPP party in Tasikmalaya was elected as Regent of Tasikmalaya in 2001. This opportunity was used as a momentum to achieve the missionary vision of the Tholiban Brigade and FPI. In this case, the formulation of the Vision and Strategic Plan (Restra) of the Tasikmalaya Regency received full attention from the Tholiban Brigade. The preparation of this strategic plan refers to PP. 108/2000, which states that each district or city must have a strategic plan as a reference in 
development. Practically, the Tholiban Brigade, together with Islamic organizations and Islamic parties, demanded the substance of Islamic law ideas in the strategic plan.

The 2001-2005 Tasikmalaya District Strategic Plan as outlined in Perda No. 13/2001 states that the vision of Tasikmalaya Regency as a district "which is religious / Islamic puts itself into a developed district in West Java in 2010". The Regent of Tasikmalaya, Tatang Farhanul Hakim, also issued a circular with Islamic law's nuances. For example, Circular No. 451 / SE / Sos / 2001 concerning Efforts to Improve the Quality of Faith and Faith. In 2003 this vision was revised by Regulation No. 13/2003, where the vision was changed to "Tasikmalaya which is religious / Islamic as a district that is advanced and prosperous and competitive in the field of business pastimes in West Java (Setda Kab. Tasikmalaya, 2010).

The birth of radical mass organizations such as the Tholiban Brigade and the FPI cannot be separated from their leaders, often called the ajengan bendo groups. Most of them have a relationship with the Miftahul Huda Islamic Boarding School or what is often referred to as the Manonjaya Islamic Boarding School. The figures include Ajengan Zenzen from the Sulalatul Huda pesantren, Ajengan Asep Mausul from the Miftahul Huda Islamic Boarding School Ajengan Mubin, an alumnus of the Manonjaya Islamic boarding school.

Pesantren Manonjaya is known as a traditional pesantren which has specific characteristics. Most of his fiqhiyyah teachings were based on the Shafi'i school of thought. Shafi'i is one of the four great traditions of Islamic figh in Sunni Islam in the world. Members of the Nahdlatul Ulama refer to themselves as ahlus sunnah wal jama'ah, but the idea of enforcing Islamic law has long been growing in this pesantren. This statement is understandable because this pesantren was founded by Khoer Affandi, a DI (Darul Islam) figure in Tasikmalaya. Many figures and alumni are active in practical politics, such as Asep Mousul and Ajengan Mubin, both at the local and national levels. They co-founded the Indonesian Mujahidin Council (MMI) in August 2000 (Naipospos, 2010).

According to one informant (AA, interview, 18 September 2013), the number of members of the Tholiban Brigade was estimated at 6,000 people. Most of its members are students of the Miftahul Huda Islamic boarding school, Sulalatul Huda, and its networks, such as the Nurul Jaza Islamic Boarding School, in South Tasikmalaya. Many of his students joined the Santri Regiment (RESAN) and the Tasikmalaya Solidarity of 
Muslims (TSM) who were involved in the sweeping action with the Tholiban Brigade. Pesantren became the mass base of the Tholiban Brigade mass organization.

In the context of regeneration, the Tholiban Brigade organization can be followed by anyone. The general public can join this organization. There is no special recruitment in the process of legalizing membership of the Tholiban Brigade. Culturally, joining the community to the Brigade Tholiban organization usually begins with participation in Thursday night recitation at the Miftahul Huda Islamic Boarding School. Also, not a few joined this organization through direct involvement in raids or sweeping immorality. Most of those who expressed interest in joining the Tholiban Brigade, from among the general public were former thugs who had either converted or repented. These former thugs were used by this organization, especially in actions and actions related to immorality.

Based on their motivation, most Tholiban Brigade members stated that they were participating because they wanted to carry out Amar ma'ruf nahi munkar. However, not a few of the members stated that they were just "hitchhiking" or wanted to take shelter behind the Tholiban Brigade's greatness. Some even have political motivations, where their participation in this organization aims to take advantage of the greatness and influence of Ajengan Zenzen and Asep Mousul. Meanwhile, in fostering members, the Tholiban Brigade organization routinely provides spiritual training and training. It is done mainly in recitation, which is done every Thursday night at the Miftahul Huda Islamic boarding school.

Besides, routine recitation as a form of member guidance is carried out every month. The implementation is carried out in turns at the place or secretariat of the leadership in the Tholiban Brigade branches. Usually, this coaching is directly carried out by Ajengan Zenzen. Apart from spiritual training, members of the Tholiban Brigade also receive physical training in martial arts and karate training. It is done as a form of provision and preparation for physical preparedness, especially in carrying out actions or measures to prevent disobedience.

Most people perceive the Tholiban Brigade's existence as a da'wah movement as a radical movement that carries out da'wah patterns in a problematic way. Actions and actions such as sweeping the place of immorality, dissolving gambling places, and dimly lit stalls, prohibiting alcoholic beverages, and so on, have resulted in various community responses. The pros and cons of community support for the Tholiban 
Brigade movement have become polemic and debated. In this case, Poston (1991) classifies missionary philosophies of Muslims into two forms, namely defensive-pacifist and offensive-activist da'wah. These two patterns indicate Islam's effort, which is related to the relationship between da'wah, jihad, and practice in religion (Fikri, 2014: 55).

Da'wah is oriented as an effort to create an ideal society. Namely, a social order with strong monotheism, a complete foundation of faith, and noble practice by the foundation of faith. The da'wah management carried out by Rasulullah Saw is guided by the main da'wah book, al-Quran, which teaches how important it is to do Amar maruf and nahi munkar by paying attention to segmentation and the needs of the object of da'wah (madh'u). The examples of preaching that Rasulullah Saw did were varied. Rasulullah always pays attention to his object's condition, social background, level of knowledge and skills, economic status, including in terms of developing strategies (siyasah) or his da'wah politics (Rustandi \& Sahidin, 2019: 363364).

It is feared that radical actions and actions have the potential to give birth to acts of terrorism. It is based on the doctrine of understanding about da'wah's obligation, which must be accompanied by the necessity of jihad. The radical terrorism movement's potential is suspected as a condition that is seen as oppression, injustice, and injustice (Setiadi, 2020: 4). In this case, the Tholiban Brigade's appearance, as conveyed by the informant, was based on conditions that displayed the moral degradation of Muslims in Tasikmalaya - starting from the desire to change the moral order of society, so that the existence of the Tholiban Brigade requires the support of the movement's formal legality and regulation, especially from policymakers in Tasikmalaya.

\section{The Socio-Historical Motive of the Tholiban Brigade}

The 1996 riots that caused physical damage in Tasikmalaya often became the spirit of the emergence of potential socio-religious dynamics in people's lives. The history of religious movements with political nuances in Tasikmalaya had happened long before, namely during the struggle for the DI / TII movement in 1949, which was proclaimed by the figure S.M. Kartosuwirjo, a young man from Central Java who later married a Sundanese girl (Dengel, 2011).

Another movement was Komando Jihad (Komji) from 1976-1980 in various regions, such as Sumatra, West Java, Central Java, to East Java. 
Komando Jihad was driven by Ismail Pranoto in Sumatra, while in West Java, it was moved by Warman. Various actions and events involving this group, such as terror, robbery, bombing, and murder. The Komji movement also occurred in Tasikmalaya and subsided by the 1980 s (Mubarak, 2008: 76-77).

The series of events of the Islamic movement above, it seems, is still challenging to eliminate in Tatar Priangan. It is due to various facts and reasons that can grow in society so that they reappear in the present era after a long period of political closure during the Old Order and New Order periods. The emergence of the Tholiban Brigade movement in Tasikmalaya cannot be separated from the socio-historical ties that have helped maintain and strengthen the Islamic ideological movement's potential, which is full of political power movements. The Islamic ideological movement takes the spirit of da'wah as a motive for spreading and implementing Islam in people's lives. It can be seen from the way and targets of the movement. The spirit of preaching that is carried out is oriented to personal change and seeks to build change in the context of the state.

Based on the opinion, mass actions, and movements, the Tholiban Brigade was born because of several Islamic figures' anxiety in Tasikmalaya. This anxiety is mainly related to the rampant behavior violations of ethics and religious norms in society. This phenomenon is strengthened by the deviation of social behavior from the younger generation, both in the form of immoral acts, crime, and other youthful delinquencies such as narcotics, alcohol, free sex, etc. Besides, the clashes that often occur between thuggish groups in society. It led to the emergence of socio-religious movements such as the Tholiban Brigade. Ideologically, the Tholiban Brigades have similarities with the Muslim Brotherhood (IM) movement in Egypt, the Hamas movement in Palestine, and the Islamic Taliban movement in Afghanistan (Chandrasekaran, 2012). Where these Islamic movements are formed to ensure the application of Islamic rules in people's lives. The spirit of da'wah, which is used as a motive for the movement, is oriented towards transforming society both from the individual and communal side. What distinguishes these Islamic movements are the efforts, processes, and methods undertaken to actualize their da'wah goals.

According to one informant (D, interview September 2, 2013) stated that the difference between the Tholiban Brigade movement in Tasikmalaya and the Middle East Taliban movement is the strengthening of Islamic da'wah, which is oriented towards achieving the organization's 
mission, namely "informing about Islam and warning Muslims who have come to the truth. to him". His obsession is to Islamize, especially the rulers who behave wrongly. The basic concept in achieving its goal is to try to shift society's existence from ignorance towards knowledgeable, thoughtful, and insightful people. So, in the end, it can be implemented as a hope in a real manifestation guided by the concept of Islam in a comprehensive manner (Nuansa Post, accessed January 1, 2012).

Ajengan Zenzen (now the late) leader of the Sulalatul Huda Islamic Boarding School as BT is known to be good at politics. He did not hesitate to form a coalition with candidates for mayor and regent in passing regional sharia regulations, as happened in 2007. Some of his cadres passed to Senayan, such as Asep Mausul, who is also the Miftahul Huda Islamic Boarding School leader who became a member of the Indonesian Parliament from the PPP Party (Hasani \& Naipospos, 2010: 183-184). Besides, Tatang Farhanul Hakim, head of PPP Tasikmalaya Regency, became regent in 2001. When Tatang Farhanul Hakim served as Regent of Tasikmalaya, he issued circular letters nuanced with Islamic law, such as Circular No. 451 / SE / Sos2001 / concerning efforts to improve the quality of faith and piety.

In a global context, the Tholiban Brigade is often perceived as a network of radical movements worldwide. BT is considered an extension of the Taliban, IM, and Hamas movement. This perception has been challenged, as expressed by Ruhanudin, Head of BT Kab. According to him, Tasikmalaya that the Tasikmalaya Tholiban Brigade movement has no connection with the Taliban in Afghanistan or Pakistan. However, the ideological principles have in common, which are not much different from the Muslim Brotherhood in Egypt and the Hamas movement in Palestine and other Islamic movements. As expressed by it, the difference is in actualizing the goal and the way of expressing it.

"Unlike the Taliban in the Middle East, a large organization that has gone far into the political arena, the Tholiban Tasikmalaya movement is still limited to preaching Islamiyah according to its mission, which is" to inform about Islam and warn Muslims who have come to the truth to him (interview results in October 2013). "

Meanwhile, regarding the concept of leadership, which is used as BT's missionary mission, Ruhanudin believes that there are no leaders in Indonesia who indeed carry a mandate. It can be said that all of them are more dominant in selfishness than paying attention to the community's 
interests. Ruhanudin took the role of a leader, such as Ayatollah Khomeini when he led Iran. According to him, a leader should be modest and far from being mundane. On this basis, BT is of the view that it is necessary to believe the leader of injustice, which is one of the objectives of the Tholiban Brigade's mission.

Practically, the Tholiban Brigade's strategy in achieving its mission is carried out through da'wah activities that seek to provide understanding to the community. Every Tholiban Brigade member carries out the community propagation movement strategy through da'wah sir or door to door.

"Currently, Tholiban Tasikmalaya is only concerned with monitoring, because to boost a moral crisis, it is necessary to have a combination of thoughts and understandings that are the same with society. Therefore, to achieve its goals, the Taliban, which currently has a membership of approximately 6,000 people and spreads in remote areas of Tasikmalaya, moves from conveying understanding to the public through da'wah, which is carried out silently or arguably guerrilla door-to-door "da'wah sir" (Results of an interview with the US, 19 May 2014).

So far, the Tholiban Brigade political da'wah movement has been carried out by participating in the contestation of democracy through a coalition support process with legislative or executive candidates who have the potential to win. It is proven by their involvement in several political moments, such as Pilwalkot Tasikmalaya, Pilbup Tasikmalaya, and General Elections in 1999 and 2009. For the Tholiban Brigade organization, their involvement in political movements is an integrative part of Islamic da'wah. It refers to BT's preaching spirit in building community change. One of the concrete proofs of BT political training's success is the birth of several Sharia Regional Regulations in Tasikmalaya. Meanwhile, to get involved directly in the practical political arena, most of the BT members stated that it was not time to "enter the political stage" directly.

"Not yet, but if you look at the reality of the behavior of the rulers who are corrupt and abuse the people and deviate from the Islamic concept, there is a possibility that this could happen." Furthermore, he said that at this time, he was moving to build understanding and moral strength of the community in aqidah and worship system based on Islamic rules based on the sentence tawhid La ilaaha illallah (there is no god other than the real God) "(R, Chairman of BT Kab. 
Tasikmalaya, 2013).

It was confirmed by another informant (KK, interview November 2013) that according to him:

"Currently, there is not enough strength to go further, so we do it with da'wah. We are gathering positive public opinion about the Taliban's mission to be used as energy to achieve goals. Sometimes in the face of the government authorities' arrogant attitude, they are constrained by the hypocritical religious figures lining up behind them. They do not flinch despite seeing that there are deviations because they have been supplied in the world. We will see how we will do jihad. "Dalam hal ini, jihad dapat diartikan sebagai mencurahkan usaha, kemampuan, dan tenaga. Jihad berarti menanggung kesulitan. Dalam Alquran kata jihad disebut 34 kali (Qardhawi, 2010).

Jihad, which is understood to be synonymous with the mobilization of physical force, seems to be carried out by the BT organization. Another accusation states that BT has close ties with Jamaah Islamiah (JI) in Indonesia. The similarity of ideology is a fundamental reason for the relationship between the two Islamic movements. BT figure Ruhanuddin explained about the understanding of the concept of the movement carried by each group. He explained that Tholiban Tasikmalaya, like other Islamic movements, was in opposition to the government, but in the concept of the movement, it was more social humanity. Perhaps it is different from the Taliban in Afghanistan or other Islamic movements oriented towards fadhoil (worship) so that their movements appear radical. It could have happened one day with the Tasikmalaya Taliban if only the morality of the rulers had gone beyond the limit.

That is the existence of Tholiban Tasikmalaya, an Islamic movement organization that is currently struggling during the human moral decline. His movement is considered to be coloring political performance in this country. The above statement does not appear to be a new issue, but it has existed since before independence regarding whether the state should be based on Islamic teachings or Islam should occupy the same position as other religions in Indonesia. This debate arose during the Soekarno regime in debates over the agreement in the Jakarta Charter. As a social movement, the Tholiban Brigade's existential motive is based on a sense of the same fate, a common enemy, and a common goal. This motive gives birth to a collective identity, which in turn will have an impact on the response from 
the surrounding environment. This collective identity strengthens common goals in responding to challenges, strengthens social solidarity, and forms sustainable social interactions (Setiadi, 2019: 23).

The Tholiban Brigade identifies itself as a political da'wah movement with a specific orientation. The spirit of da'wah inherent in this organization becomes the motive for the movement that underlies the movement's patterns and methods. Therefore, the Tholiban Brigade can be viewed as a socio-religious movement with an agenda of change in the context of local political, regional movements. In this case, the aspirations, participation, coalitions, and political training carried out by the Tholiban Brigade are oriented towards achieving Islamic da'wah's goals. Robert Misel states that social movements are a set of non-institutionalized beliefs and actions carried out by a group of people to promote or hinder change in society (Rafiudin, 2020: 74). The strength of the Tholiban Brigade as a socioreligious movement lies in the movement's doctrine, which is based on Islamic values.

\section{The Transformation of the Tholiban Brigade's Political Da'wah}

There is an idea expressed that "tong pareum ideologi NII lamun hayang negakeun syareat Islam di Indonesia. Teu kudu make payung bukum engke oge bakal aya sorangan, langkahna kuatken taubid ka masyarakat ku kalimat laa ilaha illallab" (If you want to uphold Islamic law, then do not let the ideology of the NII dim. There is no need to use a legal umbrella, because later it will also emerge by itself, by strengthening community tauhid) (KK informant, interview, 28 April 2013).

The spirit of the da'wah movement (religious ideology), which manifested itself in the Tholiban Brigade, did not appear to be limited to the fall of the New Order regime and the emergence of the 1998 reformation. The seeds of the Tholiban Brigade movement's religious ideology have their roots ingrained in the body of the NII ideologies. The idea and desire to implement Islamic law are deeply ingrained in the Tholiban Brigade followers' souls. BT can be said to be a post-New Order "Neo-NII." We can see this in the presence of formal juridical facts that reinforce this trend. For example, the aspirations of the community related to sharia regulations. Where the Tasikmalaya government and the DPRD officials responded to this by issuing Regional Regulations, which were the substance of the Shari'at Perda. The hope is that this regional regulation aims to create an order in the life of the people of Tasikmalaya, which is 
dignified and has a noble character. The orientation of this regulation is based on the principles of Islamic teachings, noble values, and norms that grow and develop in society while adhering to the Unitary State of the Republic of Indonesia (Archives of the Regional Government of Tasikmalaya Regency, 2009).

If we look at it, there are several main objectives in the formulation of this regional regulation, including: first, to create public awareness and understanding of the importance of social values and norms as a guide for life, both for personal life and in the life of society, nation, and State. Second, building public understanding of the consequences of behavior and actions that deviate and contradict the Islamic religion's teachings and social norms and legal regulations, both for personal life, family, community, and nation and State. Third, forming a personality for the Muslim community with akhlakul karimah, which is rooted in Al-Quran and As-sunah.

Fourth, forming a person who is not a Muslim to respect and respect the Islamic religious teachings of the majority of the Tasikmalaya people and the social norms and legal regulations that apply in Indonesia. Fifth, creating increased faith and devotion for Muslims to Allah SWT. Sixth, creating an atmosphere of community life and an environment that is harmonious, harmonious, peaceful, safe, orderly, and serene (Perda Tasikmalaya, 2009).

Furthermore, this regional regulation emphasizes the basic principles of social life based on Islamic teachings. This basic principle is binding on all Tasikmalaya people, both those who live permanently or not. In practical terms, the implementation of this regulation is oriented towards building values for social life where every Muslim is obliged to always uphold the glory of the teachings of Islam, which are derived from the Koran and assunnah as demands and guidelines for life, both in an individual and communal context.

The spirit of Amar ma'ruf nahi munkar and rahmatan lil Alamin is a binding principle for the Tholiban Brigade in maintaining the enforcement of Islamic law in Tasikmalaya. These two sentences have the consequence that every Muslim is obliged to prevent and avoid despicable acts and actions that cause loss and collapse of morals, morals, and social life. In this case, the Shari'a perda regulates the prevention of the community's activities or actions that are despicable and are considered to have a significant impact on tyranny. For example, acts of corruption and abuse 
of office and authority for officials, adultery and prostitution, both sexes and homosexuals or lesbians, gambling of various types, alcohol, and food containing alcohol that is addictive and intoxicating, use of narcotics, substances. Addiction and other illegal drugs, abortion, pornography, usury and bondage practices, shamanism due to shirk, thuggery, and deviant sects spread. Besides, this regional regulation also contains methods and norms of dress following Islamic teachings and social norms of the Tasikmalaya people (Tasikmalaya City Government Archives on Islamic Sharia Regional Regulation Chapter 2 Article 5).

Table 1.

List of Islamic Sharia Rules in Tasikmalaya

\begin{tabular}{|c|c|c|}
\hline No & Islamic Sharia Rules & Year \\
\hline 1 & Perda Kab. Tasikmalaya No. 28/2000 tentang Perubahan & 2000 \\
\hline 2 & $\begin{array}{l}\text { Pertama Perda No. 1/2000 tentang Pemberantasan Pelacuran } \\
\text { Surat Edaran Bupati Tasikmalaya No. 451/SE/04/Sos/2001 } \\
\text { tentang Upava Peningkatan Kualitas Keimanan dan Ketaqwaan. }\end{array}$ & 2001 \\
\hline 3 & $\begin{array}{l}\text { Perda Kab. Tasikmalaya No. 3/2001 tentang Pemulihan } \\
\text { Keamanan dan Ketertiban yang Berdasarkan lepada Ajaran } \\
\text { Moral, Agama, Etika, dan Nilai-Nilai Budaya Daerah }\end{array}$ & 2001 \\
\hline 4 & $\begin{array}{c}\text { Keputusan Bupati Tasikmalaya No. 421.2/Kep. } 326 \text { A/ } \\
\text { Sos/2001 tentang Persyaratan Memasuki Sekolah Dasar (SD), } \\
\text { Madrasah Ibtidaiyah (MI) dan Sekolah Lanjutan Tingkat Pertama } \\
\text { (SLTP) dan Madrasah Tsanawiyah (MTs) di Kabupaten } \\
\text { Tasikmalaya }\end{array}$ & 2001 \\
\hline 5 & $\begin{array}{c}\text { Himbauan Bupati Tasikmalaya No. 556.3/SP/03/Sos/2001 } \\
\text { tentang Pengelolaan Pengunjung Kolam Renang. }\end{array}$ & 2001 \\
\hline 6 & $\begin{array}{c}\text { Perda No. 13/2003 tentang Revisi Renstra Kab. Tasikmalaya } \\
\text { (Memuat Visi Religius Islami) }\end{array}$ & 2003 \\
\hline 7 & $\begin{array}{c}\text { Perda No. 5/2004 tentang Pengendalian dan Pengawasan } \\
\text { Minuman Keras }\end{array}$ & 2004 \\
\hline
\end{tabular}

Source: Observation, 2014

In socio-historical terms, the implementation of Islamic syari'at in Tasikmalaya has been started since the 2000s. This movement was initially carried out by Islamic groups in the community, including students and local Islamic organizations, which later joined the Islamic Youth Youth Forum (FBPI). Furthermore, this forum was developed through regional government channels. However, not all young Tasikmalayas support the formalization of Islamic Sharia. Because, after all, the people of Tasikmalaya have a relatively high level of heterogeneity. If it is analyzed from Islamic religious education institutions, especially pesantren, it is 
dominated by pesantren with a background in Islamic mass organizations such as Nahdlatul Ulama, Muhammadiyah, and Islamic Unity (Nasyir, 2013).

Until now, the implementation of Islamic Sharia is still under debate. Some community groups support the formalization of the implementation of Islamic law, and most others reject it. Objectively, the discussion and implementation of the formalization of Islamic law into the positive law of the state has stalled, so that the main objectives of the formulation of this regional regulation are not yet following what is expected (Mubarak \& Halimatusya'diah, 2014: 219)

The support of Islamic parties in the DPRD is strong. It refers to the votes acquired by political parties that are seen as committing the Tholiban Brigade, where the 2009 election results placed 22 members of the council. Meanwhile, community support can be seen from the existence of Islamic educational institutions such as Islamic boarding schools that support community disease eradication activities, such as the eradication of gambling, sweeping alcohol and commercial sex workers (CSWs), cleaning of dimly lit stalls which are predominantly used as places of adultery and prostitution, and other dakwah activities oriented towards the antiimmorality movement.

It was confirmed by one of the informants (E, interview, 20 March 2013) who stated that eradicating immoral behavior and acts were carried out in various ways, such as the imposition of a curfew for women basis for maintaining honor and avoiding madness. Besides, the closing of rice stalls in the month of Ramadan is a form of respect for the majority of Muslims who are carrying out the Shaum Ramadan worship. According to him, this was done to maintain the image of Tasikmalaya as a city of santri and the place where Islamic boarding schools in West Java bloom.

Based on the author's analysis, the idea of implementing Islamic Sharia regional regulations was initiated and carried out by "hardline" Islamic groups. According to the informant (AS, interview 2 September 2013), this radical group believes that efforts to regulate social life must come from the Koran and the Sunnah because both are the Islamic law's normative sources that serve as guidelines and guidelines for human life. In it already contained complete rules with all its obligations. There is a need to implement the rules in al-Quran and as-sunnah. If they do not want to accept Allah and His Messenger's rules, then in their view, it will make someone an infidel. 
Continuous action and pressure to prevent immoral actions are considered adequate and can minimize immorality in Tasikmalaya. This action was carried out in the form of a joint Islamic group consisting of several elements of society, Islamic students and youth, including the Islamic Defenders Front (FPI), the Tholiban Brigade, the Community Care Movement (GPI), the Tasikmalaya City Forum, the Street Children Association (Gaza), Paseh Forum, and Forum Pataruman. Based on observations, the movement initiated by the Tholiban Brigade received appreciation from both the community and the local government. Maintaining Tasikmalaya as a city of santri appears to be a useful propaganda strategy to strengthen the movement's vision in efforts to uphold Islamic law, both in the context of social rules and through formal juridical strategies in the form of regional sharia regulations and other regulations.

In the context of religion, the movement to enforce Islamic law in Tasikmalaya can be seen as a religious movement that involves religious elements, including belief systems, symbols, organizations, and religious practices. The aspect of belief and orientation of a religious movement is an inseparable dimension from its initiators who have basic ideas. It became natural because historically geopolitically, the Priangan Timur area in 1948 was known as the center of religious movements and political movements. It can be seen by the evidence of the Islamic State of Indonesia (NII) by Sekarmaji Maridjan Kartosuwiryo as its imam.

The religious movement carried out by the Tholiban Brigade was seen as not just a thought movement but also a movement carried out through actions and demands both on the government and on the community to obey Islamic teachings. In a sociological framework, religious movements are part of social action, which contains aspects of a world view (worldview). This world view affects the views and subjective meanings of the lives of the perpetrators. In other words, these actions are seen as meaningful actions and not merely accidental actions. In this case, Marx Weber places the world view of Islam as a specific or unique belief system because Islam has presented a new religious orientation that involves a comprehensive theological system and ethical teachings (Scoedher, 2002: 83).

Islam is not limited to dogma and ritual, but at the same time, it is a way of life that provides direction for patterns of behavior and guidelines for actions for its people. Islamic teachings regarding da'wah and jihad, for 
example, these two concepts gave birth to a strong work ethic and militancy of the movement among Muslims. Therefore, Islam is believed by its adherents to be a perfect religion (kaffah), holy (fitrah), and multidimensional with the orientation of human life, both in this world and in the afterlife. In this case, the social facts regarding Islam's concept as a religion, doctrine, and civilization can be seen from three interconnected levels. Namely, First, Islam as a belief system; Second, Islam as a culture and way of life that will integrate Muslim life into a country; Third, Islam as a political ideology whose value can socialize Muslims into separate political communities (Nasyir, 2013: 120).

In a relationship like this, according to Haidar Nasyir (2013), Islam is not limited to an aspect of belief but is in the form of an ideology and culture that gives birth to a lifestyle for the behavior (mode for action) or the action system of its adherents. This action system is manifested through its adherents' religious experiences so that it becomes a cultural structure with religious characteristics. Islam is present as a religion that gives birth to the construction of a world view and the Islamic movement's orientation (Islamic movement) of different styles. However, historically, Islamic religious thought and movements' roots refer to the development and construction of early thoughts and movements during the Umayah and Abasiyah caliphates.

The NII movement in Indonesia, for example, was often categorized as an Islamic "right" movement in the New Order era. The emergence of the NII movement was often confronted as an opponent of leftist movements such as the PKI. NII is a political movement because of its efforts to create an Islamic State. NII made Islam the basis and ideological value of its movement. The spread of Islam, both colossally and institutionally, such as pesantren institutions, is the most effective medium in instilling the NII version of Islamic values. The Tholiban Brigades are often associated with the wing right of NII expatriates in the past.

Based on the interview results, there are several arguments related to the transformation of the Tholiban Brigade missionary movement oriented to political movements. It is seen as a da'wah strategy inherited as well as a damanatari KH. Khoer Affandi (leader and founder of the Miftahul Huda Islamic Boarding School) was then followed by his son (Asep Maushul). According to one informant (KK, interview April 2013) are as follows:

"...lamun hayang ngarubah situasi masyarakat moal bisa ngan saukur gogorowokan, nitah kitu nitah kieu hese didengena, ajengan dua jam pidato oge 
moal bisa ngarubah, sabab inkonstitusional. Tah ayeunamah supaya bisa ngarubah secara konstitusional, sok arasup jadi anggota dewan kana partai numana oge, sabab lamun tos jadi anggota dewan mab boga kakawasaan." (If you want to change society's situation, you cannot just give a lecture, two hours of the lecture will also not work because it is outside the rules. Now, to change that society, the santri alumni must join the council using any party vehicle to have power).

The statement above shows the importance of power and politics to serve as a medium for da'wah. The transformation of the Tholiban Brigade da'wah movement in Indonesian local politics is seen as an attempt to narrate the spirit of Islamic da'wah in strategic spaces of the state. In the end, this political da'wah movement is oriented towards the formulation of rules that strengthen the process of upholding Islamic law, especially in Tasikmalaya.

In practice, the Tholiban Brigade carried out this movement to educate the Muslim community with Islamic preaching. Ta'lim activities are carried out to convey an ideology that is following the Koran and assunnah. According to the informants, if the community already understands and realizes that the correct ideology is based on tauhid. So by itself, it will facilitate the path to the formation of an Islamic state with formal juridical sovereignty and legality. Thus, the NII movement's ideology has a significant influence on the realization of several religious movements in Indonesia, one of which is the Tholiban Brigade movement.

One of the steps in building an ideology towards politics, the Tholiban Tasikmalaya Brigade, is to press the government to enforce Islamic Sharia. According to the informants, there are two ways or patterns to win Shari'at Islam's establishment in Indonesia. The first pattern uses faith, hijrah, and jihad. Second, the pattern championed by Muslims who want Islam as sharia in Indonesia through the participation of the democratic system under the umbrella of the Republic of Indonesia. It is just that the second pattern is the last option because, in their view, forming an Islamic state on top of a Pancasila state is tantamount to talbisul haqa bil batil (mixing right with wrong mixtures). The roots and stems are Pancasila, while the leaves and fruits are Islam, this is not possible because it contradicts the Islamic belief based on Laailaha Illallah.

He emphasized that it was not the NII that encouraged the birth of Islamic Sharia in Tasikmalaya. NII is just an inspiration that led to the birth of the Tholiban Brigade movement. 
"It is better if we cooperate with mutual respect, religious tolerance, but we are one camp. You worship Allah, and we respect you. We worship your idols; do not disturb or insult our idols. So Allah answered with the derivation of the letter Al-Kafirun. If we agree with religious tolerance, it means that we worship them together. We tolerate not getting there until lakum is punished by waliyadin (for your religion and religion).

From the above statement, it can be illustrated that NII will not ask for Islamic Sharia implementation. However, the establishment of Islamic Syaria'at needs to be fought for following the NII's pattern of struggle, namely Iman, Hijrah, and Jihad.

According to the informant ( $\mathrm{R}$, interview, 8 November 2013), the concept of tolerance in the NII movement is an effort to provide freedom in fighting for the movement's values and mission. By adapting the phrase Sekarmaji Marijan Kartosuwiryo (SMK) to Soekarno. The informant stated that SMK translated the concept of Islamic tolerance to Soekarno with the following sentence, "For you, Soekarno is your Pancasila and for me the Islamic rules that I adhere to. Please fight for nationalism with your Pancasila and we will continue to fight for my Islam". The informant further explained that:

"The concept of tolerance, who wins first, it turns out that today Allah wants to win the Pancasila camp, (the Nationalism stronghold). Nevertheless, we believe history is still and continues to go on and insha'Allah. God promises that Islam in the last days with the Prophet said will win before the world's end. According to the Vatican in his book states: a Muslim who does not believe that Islam will win at the end of time is questioned about his Islam and faith. Indonesia's ideological struggle will not stop because if an ideology is ingrained and ingrained in a person's soul, whatever ideology will never disappear unless that person dies. However, his ideology will still live and continue because the ideology he adheres to believes is true."

The Tholiban Brigade has a fundamental reason as other Muslims who understand the actual teachings of Islam, that, first, Islam is the rabbinical religion of Allah's religion which is not intervened by anyone; second, Islam is a natural (natural) religion that is not limited by territory for all corners of the world and all humans. Then he said that third, Islam is a religion of descent (flexible) in every situation. Islam has rules about how when Rosululllah saw in Mecca not yet had a strong daub, but Islamic 
principles already exist how to carry out leadership and manage leadership in times of weakness, war, and success. Islam Summuliyah religion (universal religion) covers all aspects of life.

The Tholiban Brigade strongly believes that Islam is the only teaching that is guaranteed to be true. Islam will be a pillar and ideology that grows in the archipelago to regulate the nation's life and state. For them, it is possible to replace the Pancasila ideology with Islamic Sharia values. In his narrative, one of the informants stated that:

"Yes ... if you have won who will doubt, like, if we have died seeing heaven and hell who will not believe, everything will be faith, precisely the test of faith today before we see heaven and hell; moreover we are sure of heaven's existence. And hell. Today, Islam has not won; that is Allah's test, whether people claim to be believers or not. Those who believe in the truth of Islam will continue to fight for the upholding of a rule of life as nation and state".

The NII (Tholiban Brigade) carried out the da'wah movement, how its form can be known based on its objectives. The Islamic da'wah movement carried out by the Tholiban Brigade aims to achieve Daulah Islamiyah. For BT, Daulah Islamiyyah is a missionary target that must be achieved to ensure the enforcement of Islamic law in Indonesia. Therefore, the transformation of the Tholiban Brigade dakwah movement began to be carried out in the political field to create an order of community life that implements Islamic rules and values in various aspects of life. The Islamic da'wah movement can be enforced by upholding Daulah Islamiyah (Kuswana, 2020: 325).

Regarding Daulah Islamiyyah, several da'wah strategies and stages carried out by the Tholiban Brigade are as follows; First, a personal approach through an invitation to convert to Islam while at the same time implementing Islamic teachings thoroughly. It refers to the concept of da'wah Rasulullah Saw, which invites in the way of wisdom and mauidzah hasanah. For the Tholiban Brigade, the realization of Daulah Islamiyyah must start from the manifestation of Muslim individuals. It is done through cultivating aqidah, fostering worship, and caring for muamalah among Muslim believers. Second, the invitation to jihad is fisabilillah. It refers to efforts to Islamize all components of the Muslim community completely. Islam is not a compelling religion, but calls and invites to continue to live up to Islamic values in various human life dimensions. Third, consolidation between Islamic countries in the world. It is an effort to strengthen the 
vision, mission, and objectives for the establishment of Daulah Islamiyyah. Where must stand on the same territory and be led by a leader who is believed? This consolidation was carried out without any time limitation, given that in their view, the manifestation of Daulah Islamiyyah was a vision of lifelong da'wah tied to the spirit of Amar maruf nahi munkar.

Religion and state are two entities in a social system that are complementary to each other. Both of them can reinforce each other and have the potential to become instruments that can lead to the disintegration of society. Religion can be a force in building state solidarity. Conversely, religion can also be a trigger for conflict. In religion, da'wah and politics are two essential aspects that cannot be separated to improve the people. The role of da'wah is in strengthening the understanding of the people through taklim, tarbiyah, tabligh, etc. It is an attempt to answer the role of da'i. At the same time, politics' role is to improve the ummah from the system and rules of formal legalization of state law. It strengthens the role of humans as khalifah fil-ard (Razzaq, 2014: 6). Therefore, the Tholiban Brigade was transformed into the political sphere to strengthen its preaching goals.

In this regard, there are at least three positions in the relationship between religion and state. First, Islam is seen as a religion and a state (din was daulah). Where the orientation requires an Islamic state and Islamic government (an-nizam al-Islami). Second, the view which states that Islam is only a religion, not a state. This view states that religion must be separated from the state, and the state must not interfere in religious matters. Third, the view states that Islam is the essence that underlies the values and universality of human life (Fikri, 2014: 58). It seems that the transformation of the Tholiban Brigade da'wah movement into spaces of power can be seen as an attempt to unite Islam as a religion and state. The ideals of daulah Islamiyyah inspired by the NII movement's ideology show the importance of political preaching carried out by the Tholiban Brigade. It is done as an effort to build an Islamic community order in various aspects of life.

\section{CONCLUSION}

Referring to the explanation regarding the transformation of the Tholiban Brigade social movement, it can be concluded as follows: first, the socioreligious movement was initially a response to the phenomenon of social change that developed in society. Changes in lifestyle that are against Islamic ethics. The trigger for this group's existence is to provide education about the dangers of immorality within the framework of building an 
Islamic society. The Tholiban Brigade (BT) group emerged with a missionary strategy seen as extreme and radical. The pattern of the da'wah movement is carried out through actions and actions that demand the application of Islamic law within the scope of national and state life. Thus, the development of this da'wah movement is transformed within the scope of power or politics with the hope that the BT group will receive legal guarantees and formal juridical arguments in carrying out its da'wah movement so that it is not considered to violate religious rules, social norms to the political aspect.

Second, being aware of the limited role in achieving the Amar maruf nahi munkar movement targets, the Tholiban Brigade widened its approach through practical politics. However, the practical politics of the Tholiban Brigade was only limited to carrying out its cadres or prospective leaders to become policymakers both at the central and regional levels. It is done to strengthen the mission of their da'wah movement. The Tholiban Brigade demanded that local regulations be made related to Islamic law. Third, the BT ideology is the embodiment of Islamic teachings that are comprehensive (kaffah). Socio-historically, the Tholiban Brigade movement motif was inspired by the spirit of the Daulah Islamiyyah movement. So that in the process of fostering and forming it, the Tholiban Brigade began to explore the foundation of the movement and understanding of Islam, both during the time of the prophet Muhammad Saw and digging the roots of the movement during the DI / TII era in West Java.

Fourth, the transformation of the Tholiban Brigade dakwah and political movements was dynamic. This dynamic occurs because of internal friction and rejection from the community. The rejection was more due to issues related to the formalization of Islam. In practical terms, the community supports the anti-evil movement and immorality carried out by the Tholiban Brigade. However, some people disagreed with the way and approach of the Tholiban Brigade in carrying out these actions. On this basis, the ups and downs of the Tholiban Brigade da'wah movement have implications for the people's life order in Tasikmalaya. The Tholiban Brigade emerged as an Islamic community organization oriented towards the manifestation of Amar maruf nahi munkar. This embodiment is seen as a da'wah target that must change the Tasikmalaya and Indonesian people in individual and communal spheres. 


\section{REFERENCES}

Aripudin, A. (2013). Brigade Tholiban: Politik Santri antara Dakwah dan Motivasi Ekonomi, Jurnal Millah UII Yogyakarta.

Chandrasekaran, R. (2012). Indonesian-Style Taliban Fights for Islamic Law. The Washington Post.

Dengel, H. H. (2011). Darul Islam-NII dan Kartosuwiryo Angan-Angan yang Gagal. Jakarta: Grafiti.

Departemen Agama RI. (2012). Al-Quran dan tarjamahnya. Bandung: Khazanah Intelektual.

Dodi, L. (2017). Metamorfosis Gerakan Sosial Keagamaan: Antara Polemik, Desiminasi, Ortodoksi, dan Penerimaan terhadap Ideologi Lembaga Dakwah Islam Indonesia (LDII), Al-Tabrir, 17(1), 227-246. (DOI: 10.21154/altahrir.v17i1.880).

Fikri, Z. (2014). Politik Islam antara Dakwah dan Orientasi Kekuasaan, Alhadharah Jurnal Ilmu Dakwah, 13(26), 55-60. (DOI: http://dx.doi.org/10.18592/alhadharah.v13i26.1708).

Gunawan. (2018). Transformasi Sosial dan Gerakan Keagamaan, AthThariq Jurnal Dakwah dan Komunikasi, 2(1), 1-20.

Hasani, I., \& Naipospos, B. T. (ed) (2010). Radikalisme Agama dan Implikasinya Terhadap Jaminan Kebebasan Beragama/Berkeyakinan di Jabidetabek dan Jawa Barat, Wajah Para Pembela Islam. Jakarta: Pustaka Masyarakat Setara.

http://nuansapost.com/2012/01 Eksistemsi Brigade Tholiban di Kabupaten Tasikmalaya, diakses pada April 2013.

https://www.kompas.com, diakses tanggal 4 Agustus 2013

Ja'far (2015). Tarekat dan Gerakan Sosial Keagamaan Syakh Hasan Maksum, Teosofi: Jurnal Tasawuf dan Pemikiran Islam, 5(2), 269-293. (http://jurnalfuf.uinsby.ac.id/index.php/teosofi/article/view/107/ 95).

Kuswana, D. (2020). Transformasi Agama dari Ideologi Ke Politik: Brigade

Tholiban di Priangan Timur Jawa Barat Indonesia, Asyahid Journal of Islamic and Quranic Studies (AJIQS), 2(1), 317-336. (http://jurnal.staialfalah.ac.id/index.php/sya/article/view/37).

Mubarak, M. Z. (2008). Geneologi Islam Radikal di Indonesia; Gerakan, Pemikiran dan Prospek Demokrasi. Jakarta: LP3ES.

Muslim. (2019). Gerakan Sosial Keagamaan FPI (Front Pembela Islam), Asyahid Journal of Islamic and Quranic Studies (AJIQS), 1(2), 88-101. 
(http://jurnal.staialfalah.ac.id/index.php/sya/article/view/28).

Naipospos, B. (2010). Para Pembela Tuban. Jakarta: Grafiti.

Nasyir, H. (2013). Islam Syariat. Bandung: Mizan.

Nirwana AN, A. (2016). Akulturasi Politik dalam Dunia Dakwah, Substantia, 18(2), 207-218. (https://jurnal.arraniry.ac.id/index.php/substantia/article/view/3007/2150).

Nugraha, F. (2018). Gerakan Ekonomi Keagamaan dan Politik Identitas

Muslim Pedesaan (Studi di BMT Dana Akhirat Kecamatan Arjasari

Kabupaten Bandung), Jurnal Bimas Islam, 11(4), 693-722. (DOI:

https://doi.org/10.37302/jbi.v11i4.67).

Qardhawi, Y. (2010). Fiqh Jihad. Bandung: Mizan.

Rafiudin. (2020). Agama dan Kekuasaan (Studi Pada Gerakan Sosial

Keagamaan Warga Al-Khairiyah Cilegon-Banten), Tsaqofah; Jurnal Agama dan Budaya, 18(1), 65-84. (http://jurnal.uinbanten.ac.id/index.php/tsaqofah/article/view/31 $82 / 2331)$

Razzaq, A. (2014). Dinamika Dakwah dan Politik dalam Pemikiran Islam Modernis di Indonesia, Wardah, 15(1), 7-15 (https://doi.org/https://doi.org/10.19109/wardah.v15i1.202)

Rustandi, R., \& Sahidin, S. (2019). Analisis Historis Manajemen Dakwah Rosulullah Saw dalam Piagam Madinah, Tamaddun: Jurnal Sejarah dan Kebudayan Islam, 7(2), 362-387. (DOI: 10.24235/tamaddun.v7i2.5503.g2562).

Rosa, A. (2014). Politik Dakwah dan Dakwah Politik di Era Reformasi Indonesia, Walisongo: Jurnal Penelitian Sosial Keagamaan, 22 (1), 57-82. (DOI: 10.21580/ws.22.1.259).

Scoedher, R. (2002). Max Weber Tentang Hegemoni Sistem Kepercayaan (terj. Ratna Noviani). Yogyakarta: Kanisius.

Sekretariat Daerah Kabupaten Tasikmalaya. (2009). Arsip Pemerintab Daerah Tasikmalaya

Sekretariat Daerah Kabupaten Tasikmalaya. (2010). Dokumen Resmi Berita Tasikmalaya.

Sekretariat Daerah Kabupaten Tasikmalaya. (2010). Peraturan Daerah Tasikmalaya Nomor 12 Tabun 2009

Sekretariat Daerah Kabupaten Tasikmalaya. (2010). Peraturan Daerah Syariat Islam Bab 2 Pasal 5.

Setiadi, O. (2019). Gerakan Islam Politik: Problem Ideologi Radikal, Global Jihad, dan Terorisme Keagamaan, Politea: Jurnal Politik Islam, 2(1), 1- 
28. (DOI 10.20414/politea.v2i1.1345). 